\title{
Synthesis of Some Salicylaldehyde-Based Schiff Bases in Aqueous Media
}

\author{
Sunita Bhagat, Nutan Sharma, and Tejpal Singh Chundawat \\ Organic Synthesis Research Laboratory, Department of Chemistry, A.R.S.D. College, University of Delhi, New Delhi 110021, India
}

Correspondence should be addressed to Sunita Bhagat; sunitabhagat28@rediffmail.com

Received 21 May 2012; Revised 4 August 2012; Accepted 10 August 2012

Academic Editor: Albert Demonceau

Copyright (C) 2013 Sunita Bhagat et al. This is an open access article distributed under the Creative Commons Attribution License, which permits unrestricted use, distribution, and reproduction in any medium, provided the original work is properly cited.

\begin{abstract}
A new efficient and environmental friendly procedure for the synthesis of a series of salicylaldehyde-based schiff bases under microwave irradiation is described. The method is compared with the conventional method also. The present work involves condensation of salicylaldehyde with various aromatic amines in water under microwave irradiation. A judicious choice of the solvent and reaction conditions allowed the final products to be generated in excellent yields in a one-step procedure, whereas experiments under thermal conditions led to lower yields with tedious work-up. Microwave irradiation method gives advantages like reduction in reaction time, increase in conversion, reduced wastes, and good yields. The structures of synthesized compounds were confirmed by IR, 1HNMR, and Mass Spectra data.
\end{abstract}

\section{Introduction}

There has been growing concern over the environmental impact of chemicals so that cleaner green reaction conditions in synthetic processes have been advocated. The tight legislation to maintain greenness requires us to prevent the generation of waste, avoid use of auxiliary substances (e.g., organic solvents, additional reagents), and minimize the energy requirement. In this context, the use of water as the reaction medium offers several advantages as (a) it is cheap, noninflammable, nontoxic, and safe to use $[1,2]$, (b) its unique physical and chemical properties often increase the reactivity or selectivity, which sometimes is unattainable in organic solvents [3], and (c) it eliminates the additional efforts required to make the substrates/reagents dry before use and thus reduces/eliminates the consumption of drying agents, energy, and time.

Schiff bases are typically formed by the condensation of a primary amine and an aldehyde which involves the use of organic solvents such as methanol, tetrahydrofuran (THF), and 1,2-dichloroethane (DCE) [4]. Microwave-assisted preparation of a series of Schiff base without solvent [5] has also been reported. Comparison of the three ways to synthesize simple Schiff base has been made and microwave irradiation was found to be the simplest way to synthesize the Schiff base [6].

Schiff base compounds are very popular ligands because of their easy formation and rich coordination chemistry with a large variety of metal ions, that has allowed their use as catalysts in different asymmetric reactions [7, 8]. Salicylaldehyde-based Schiff bases complexes of 2-amino1,3,4-thiadiazole have been screened for antibacterial activity against several bacterial strains such as Escherichia coli, Staphylococcus aureus, and Pseudomonas aeruginosa [9]. The antibacterial potency of these Schiff bases increased upon chelation/complexation, against the tested bacterial sixties, opening new approaches in the fight against antibiotic resistant strains. Considering all these findings, we hereby report the microwave-assisted synthesis of some salicylaldehydebased Schiff bases in aqueous media.

It is worthwhile to mention here that the synthesis of these Schiff bases is known [10-13] in the literature involving tedious process using methanol/ethanol as solvent and requires longer reaction time. In general the reported syntheses of Schiff bases involving condensation reactions requires drastic conditions namely, use of Dean Stark apparatus, use of catalyst, higher temperature, and longer reaction time [14]. Fluorinated Schiff bases reported in this paper 
are also equally important because of the effects of fluorine substitution on inter- and intramolecular forces which affect binding of ligands, and thus introduce receptor subtype selectivity in the body $[15,16]$. The scope and generality of this process is illustrated with respect to salicylaldehyde and various fluorinated amines.

In conclusion, we describe a green and efficient method for the synthesis of Schiff bases in aqueous media (Scheme 1). The easy workup, facile conditions, fast reaction rates, good yields, and selectivity of the reaction make the present methodology attractive.

\section{Experimental}

Melting points were determined in open capillary tubes and are uncorrected. The purity of the compound was checked on silica-gel-coated aluminium plates (Merck). IR spectra were recorded in $\mathrm{KBr}$ on a Perkin Elmer Spectrum RX-1 FTIR spectrophotometer. ${ }^{1} \mathrm{H}-\mathrm{NMR}$ and ${ }^{13} \mathrm{C}$-NMR spectra were measured on Jeol JNM-ECX400P at $400 \mathrm{MHz}$. Microwave irradiations were carried out in microwave synthesizer, (CEM-Discover). All chemicals used were of analytical grade.

\section{Conventional Method}

Schiff bases are prepared by condensation of salicylaldehyde $(0.004 \mathrm{~mol})$ with various aromatic amines (2a-e) $(0.004 \mathrm{~mol})$ in water $(10 \mathrm{~mL})$ and the mixture was stirred at ambient temperature. The progress of reaction was monitored by TLC. On completion of reaction the product was separated as yellow-coloured amorphous product which was filtered, dried, and recrystallized from methanol.

\section{Microwave Method}

A mixture of salicylaldehyde $(0.004 \mathrm{~mol})$ and substituted aromatic amines $(2 \mathrm{a}-\mathrm{e})(0.004 \mathrm{~mol})$ in water $(1 \mathrm{~mL})$ were added in microwave tube. The contents were subjected to microwave irradiation at $200 \mathrm{~W}$ for about $30 \mathrm{sec}-2 \mathrm{~min}$. Progress of the reaction was monitored by TLC. After the completion of the reaction, solid product was obtained in reaction mixture which was filtered and recrystallized with methanol. Recrystallization provides the title compounds as solid crystals.

\section{Results and Discussion}

Novel green method using water as solvent for synthesis of schiff's base has been established. The synthetic scheme has been given in Scheme 1. The results summarized in Table 1.

Reaction for the synthesis of $3 a-e$ was standardized by performing the synthesis of $3 \mathrm{a}$ at different temperatures starting from ambient temperature to $80^{\circ} \mathrm{C}$ as shown in Table 1 . However, on comparing the progress of reaction, the best yields were obtained at a temperature of $70^{\circ} \mathrm{C}$, therefore synthesis of compounds (3b-e) was carried out at this temperature. Moreover reaction time reported was according to the completion of reaction at a microwave power
TABLE 1: Comparison of yield of Schiff base (3a) at different temperatures under microwave condition.

\begin{tabular}{lccc}
\hline \multirow{2}{*}{ Compound } & \multicolumn{2}{c}{ Microwave method } & \multirow{2}{*}{ Yield \% } \\
& Power & Temp. & \\
\hline $3 \mathrm{a}$ & $200 \mathrm{~W}$ & Ambient & 30 \\
$3 \mathrm{a}$ & $200 \mathrm{~W}$ & $50^{\circ} \mathrm{C}$ & 65 \\
$3 \mathrm{a}$ & $200 \mathrm{~W}$ & $60^{\circ} \mathrm{C}$ & 80 \\
$3 \mathrm{a}$ & $200 \mathrm{~W}$ & $70^{\circ} \mathrm{C}$ & 95 \\
$3 \mathrm{a}$ & $200 \mathrm{~W}$ & $80^{\circ} \mathrm{C}$ & 96 \\
\hline
\end{tabular}

of $200 \mathrm{~W}$. The Microwave irradiation method is compared (in terms of time and yield \%) with conventional method for the synthesis of Schiff bases as illustrated in Table 2.

\subsection{Product Characterization Data}

2-[(2,4-Difluoro-phenylimino)-methyl]-phenol (3a) [10]. Yellow solid, M.p. $96-98^{\circ} \mathrm{C}$, IR $\left(\mathrm{KBr}, \mathrm{cm}^{-1}\right)$ : 2921.64, 1615.96, 1490.71, 1282.72, 1144.23, ${ }^{1} \mathrm{HNMR}\left(400 \mathrm{MHz}, \mathrm{CDCl}_{3}\right): \delta=$ $12.96(1 \mathrm{CH}, \mathrm{s}), 8.68(1 \mathrm{H}, \mathrm{s}), 7.40(2 \mathrm{H}, \mathrm{d}), 7.28(1 \mathrm{H}, \mathrm{m}), 7.04$ $(1 \mathrm{H}, \mathrm{t}), 6.95(3 \mathrm{H}, \mathrm{m}) .{ }^{13} \mathrm{C}-\mathrm{NMR}\left(\mathrm{CDCl}_{3}\right)(\delta \mathrm{ppm}): 164.32$, $162.30,161.18,159.82,136.99,133.62,132.45,121.88,119.82$, $119.16,117.53,111.55,104.98 . \mathrm{M} / \mathrm{S}: 234.1(\mathrm{M}+1)$.

2-[(4-Chloro-phenylimino)-methyl]-phenol (3b) [11]. Golden solid, M.p. $70-72^{\circ} \mathrm{C}$, IR $\left(\mathrm{KBr}, \mathrm{cm}^{-1}\right)$ : 2923.53, 1616.99, 1484.66, 1282.13, 830.12, ${ }^{1} \mathrm{HNMR}\left(400 \mathrm{MHz}, \mathrm{CDCl}_{3}\right): \delta=$ $13.02(1 \mathrm{H}, \mathrm{s}), 8.59(1 \mathrm{H}, \mathrm{s}), 7.40(2 \mathrm{H}, \mathrm{d}), 7.38$ (2 H, d), 7.22 $(2 \mathrm{H}, \mathrm{dd}), 7.02(1 \mathrm{H}, \mathrm{d}), 6.95(1 \mathrm{H}, \mathrm{t}) .{ }^{13} \mathrm{C}-\mathrm{NMR}\left(\mathrm{CDCl}_{3}\right)$ ( $\delta \mathrm{ppm}): 162.97,161.08,147.01,133.71,133.42,132.47$, $132.38,129.51,122.43,119.77,119.19,117.30 . \mathrm{M} / \mathrm{S}: 232.1(\mathrm{M}$ $+1)$.

2-[(2,3,4,5-Tetrafluoro-phenylimino)-methyl]-phenol (3c). Greenish solid, M.p. $140-142^{\circ} \mathrm{C}$, IR $\left(\mathrm{KBr}, \mathrm{cm}^{-1}\right): 2921.81$, 1608.12, 1487.30, 1050.26, 765.99. ${ }^{1} \mathrm{HNMR}(400 \mathrm{MHz}$, $\left.\mathrm{CDCl}_{3}\right): \delta=12.43(1 \mathrm{H}, \mathrm{s}), 8.63(1 \mathrm{H}, \mathrm{s}), 7.44(2 \mathrm{H}, \mathrm{dd}), 7.06$ $(1 \mathrm{H}, \mathrm{d}), 6.98(2 \mathrm{H}, \mathrm{m}) .{ }^{13} \mathrm{C}-\mathrm{NMR}\left(\mathrm{CDCl}_{3}\right)(\delta \mathrm{ppm}): 166.19$, $161.30,140.25,136.99,134.55,133.72,132.95,132.66,119.83$, $119.49,118.58,117.61,103.07 . \mathrm{M} / \mathrm{S}: 270.1(\mathrm{M}+1)$.

2-[(4-Bromo-phenylimino)-methyl]-phenol (3d) [11, 12]. Greenish solid, M.p. $98-100^{\circ} \mathrm{C}$, IR $\left(\mathrm{KBr}, \mathrm{cm}^{-1}\right): 2924.05$, $1616.74, \quad 1482.31, \quad 1282.45, \quad 827.96, \quad 753.91,{ }^{1} \mathrm{HNMR}$ $\left(400 \mathrm{MHz}, \mathrm{CDCl}_{3}\right): \delta=12.99(1 \mathrm{H}, \mathrm{s}), 8.59(1 \mathrm{H}, \mathrm{s})$, $7.53(2 \mathrm{H}, \mathrm{d}), 7.39$ (2H, m), $7.14(2 \mathrm{H}, \mathrm{d}), 7.02(1 \mathrm{H}, \mathrm{d}), 6.90$ $(1 \mathrm{H}, \mathrm{t}) .{ }^{13} \mathrm{C}-\mathrm{NMR}\left(\mathrm{CDCl}_{3}\right)(\delta \mathrm{ppm}): 162.99,161.13,147.47$, $133.43,132.46,132.39,122.79,120.34,119.81,119.20,117.32$. $\mathrm{M} / \mathrm{S}: 276.1(\mathrm{M}+1)$.

2-[(4-Fluoro-phenylimino)-methyl]-phenol (3e) [13]. Yellow solid, M.p. $72-74^{\circ} \mathrm{C}$, IR $\left(\mathrm{KBr}, \mathrm{cm}^{-1}\right)$ : 2923.58, 1613.69, 1490.44, 1272.75, 837.45, ${ }^{1} \mathrm{HNMR}\left(400 \mathrm{MHz}, \mathrm{CDCl}_{3}\right): \delta=$ $13.01(1 \mathrm{H}, \mathrm{s}), 8.58(1 \mathrm{H}, \mathrm{s}), 7.37(2 \mathrm{H}, \mathrm{m}), 7.26(2 \mathrm{H}, \mathrm{m}), 7.12$ $(2 \mathrm{H}, \mathrm{m}), 7.03(1 \mathrm{H}, \mathrm{d}), 6.94(1 \mathrm{H}, \mathrm{t}) .{ }^{13} \mathrm{C}-\mathrm{NMR}\left(\mathrm{CDCl}_{3}\right)(\delta$ 


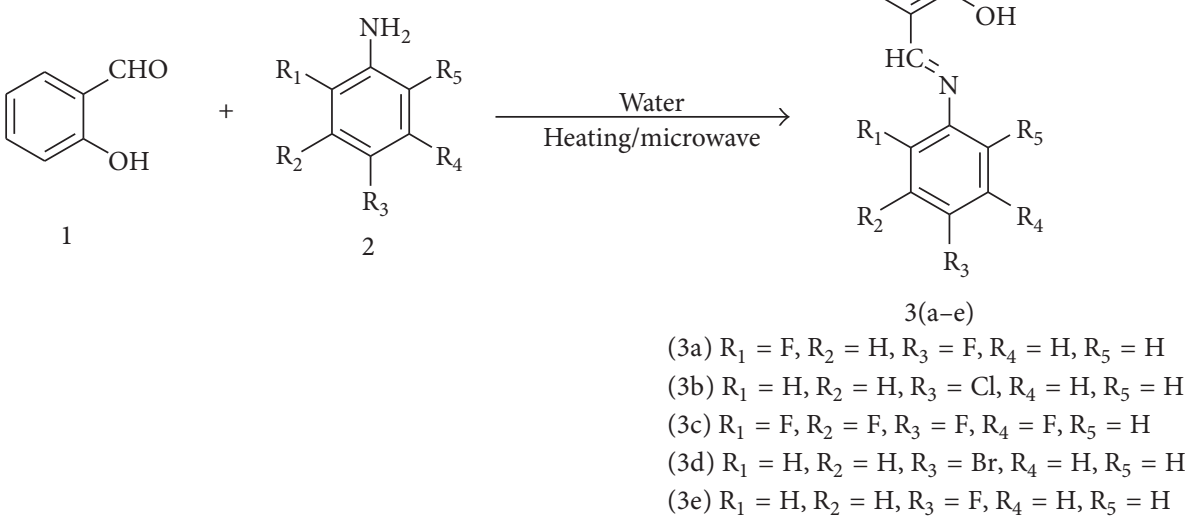

Scheme 1: Synthesis of Schiff bases.

TABLE 2: Comparison of microwave and conventional method.

\begin{tabular}{lccccccc}
\hline \multirow{2}{*}{ Comp. } & \multicolumn{2}{c}{ Microwave method } & \multicolumn{3}{c}{ Conventional method } \\
& Power & Temp. & Time $(\mathrm{sec})$ & Yield \% & Temp. & Time (hrs) & Yield \% \\
\hline 3a & $200 \mathrm{~W}$ & $70^{\circ} \mathrm{C}$ & 60 & 95 & Ambient & 2 & 70 \\
3b & $200 \mathrm{~W}$ & $70^{\circ} \mathrm{C}$ & 30 & 92 & Ambient & 1.5 \\
3c & $200 \mathrm{~W}$ & $70^{\circ} \mathrm{C}$ & 60 & 96 & Ambient & 1.5 & 75 \\
$3 \mathrm{~d}$ & $200 \mathrm{~W}$ & $70^{\circ} \mathrm{C}$ & 30 & 94 & Ambient & 1 & 72 \\
$3 \mathrm{e}$ & $200 \mathrm{~W}$ & $70^{\circ} \mathrm{C}$ & 120 & 90 & Ambient & 1.5 \\
\hline
\end{tabular}

ppm): 162.41, 160.98, 160.37, 144.61, 133.18, 133.25, 122.61, $122.52,119.11,119.05,117.21,116.28,116.06 . \mathrm{M} / \mathrm{S}: 216.2(\mathrm{M}$ $+1)$.

\section{Conclusions}

The method shown here is the most convenient way to synthesize the salicylaldimines, in which microwave irradiation plays an important role for promoting the condensation reaction of aldehyde and amine and water plays the role of eco-friendly solvent. In conclusion, a simple efficient and fast method has been developed for the synthesis of novel Schiff bases in aqueous media under microwave irradiation method.

\section{Acknowledgments}

The authors are thankful to the Department of Science and Technology (DST) women scientist scheme (WOS-A) for the financial support. No shrma is thankful to DST for INSPIRE Fellowship.

\section{References}

[1] C. J. Li, "Organic reactions in aqueous media with a focus on carbon-carbon bond formations: a decade update," Chemical Reviews, vol. 105, no. 8, pp. 3095-3165, 2005.
[2] H. Yorimitsu, H. Shinokubo, and K. Oshima, "Synthetic radical reactions in aqueous media," Synlett, no. 5, pp. 674-686, 2002.

[3] U. M. Lindstrom, "Stereoselective organic reactions in water," Chemical Reviews, vol. 102, no. 8, pp. 2751-2772, 2002.

[4] A. F. Abdel-Magid, K. G. Carson, B. D. Harris, C. A. Maryanoff, and R. D. Shah, "Reductive amination of aldehydes and ketones with sodium triacetoxyborohydride. Studies on direct and indirect reductive amination procedures," Journal of Organic Chemistry, vol. 61, no. 11, pp. 3849-3862, 1996.

[5] H. J. Yang, W. H. Sun, Z. L. Li, and Z. Ma, "The rapid synthesis of Schiff-base without solvent under microwave irradiation," Chinese Chemical Letters, vol. 13, no. 1, pp. 3-6, 2002.

[6] Z. Yang and P. Sun, "Compare of three ways of synthesis of simple Schiff bas," Molbank, vol. 2006, no. 6, Article ID M514, 2006.

[7] S. C. Gagieva, T. A. Sukhova, D. V. Savinov et al., "New fluorinecontaining bissalicylidenimine-titanium complexes for olefin polymerization," Journal of Applied Polymer Science, vol. 95, no. 5, pp. 1040-1049, 2005.

[8] A. Patti, S. Pedotti, F. P. Ballistreri, and G. T. Sfrazzetto, "Synthesis and characterization of some chiral metal-salen complexes bearing a ferrocenophane substituent," Molecules, vol. 14, no. 11, pp. 4312-4325, 2009.

[9] Z. H. Chohan, M. F. Jaffery, and C. T. Supuran, "Antibacterial $\mathrm{Co}(\mathrm{II}), \mathrm{Cu}(\mathrm{II}), \mathrm{Ni}(\mathrm{II})$ and $\mathrm{Zn}(\mathrm{II})$ complexes of thiadiazoles Schiff bases," Metal-Based Drugs, vol. 8, no. 2, pp. 95-101, 2001.

[10] D. P. Song, Y. G. Li, R. Lu, N. H. Hu, and Y. S. Li, "Synthesis and characterization of novel neutral nickel complexes bearing fluorinated salicylaldiminato ligands and their catalytic behavior for 
vinylic polymerization of norbornene," Applied Organometallic Chemistry, vol. 22, no. 6, pp. 333-340, 2008.

[11] J. S. Bennett, K. L. Charles, M. R. Miner et al., "Ethyl lactate as a tunable solvent for the synthesis of aryl aldimines," Green Chemistry, vol. 11, no. 2, pp. 166-168, 2009.

[12] W. Qingming, M. Zhu, R. Zhu et al., "Exploration of $\alpha$ aminophosphonate $\mathrm{N}$-derivatives as novel, potent and selective inhibitors of protein tyrosine phosphatases," European Journal of Medicinal Chemistry, vol. 49, pp. 354-364, 2012.

[13] P. Kathirgamanathan, S. Surendrakumar, J. Antipan-Lara et al., "Novel lithium Schiff-base cluster complexes as electron injectors: synthesis, crystal structure, thin film characterisation and their performance in OLEDs," Journal of Materials Chemistry, vol. 22, no. 13, pp. 6104-6116, 2012.

[14] S. Jie and S. Zhang, "2-arylimino-9-phenyl-1,10phenanthrolinyl-iron, -cobalt and -nickel complexes: synthesis, characterization and ethylene oligomerization behavior," European Journal of Inorganic Chemistry, vol. 2007, no. 35, pp. 5584-5598, 2007.

[15] M. Rowley, D. J. Hallett, S. Goodacre et al., "3-(4fluoropiperidin-3-yl)-2-phenylindoles as high affinity, selective, and orally bioavailable h5- $\mathrm{HT}_{2 A}$ receptor antagonists," Journal of Medicinal Chemistry, vol. 44, no. 10, pp. 1603-1614, 2001.

[16] S. Purser, R. M. Peter, S. Swallow et al., "Fluorine in medicinal chemisatry," Chemical Society Reviews, vol. 37, no. 2, pp. 320-330, 2008. 

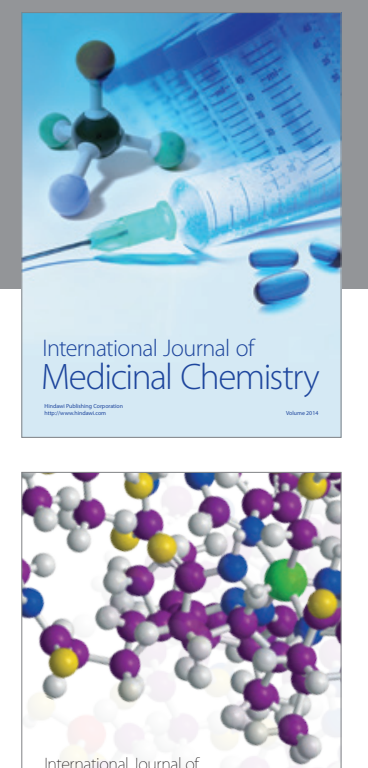

\section{Carbohydrate} Chemistry

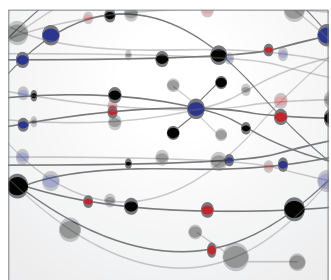

The Scientific World Journal
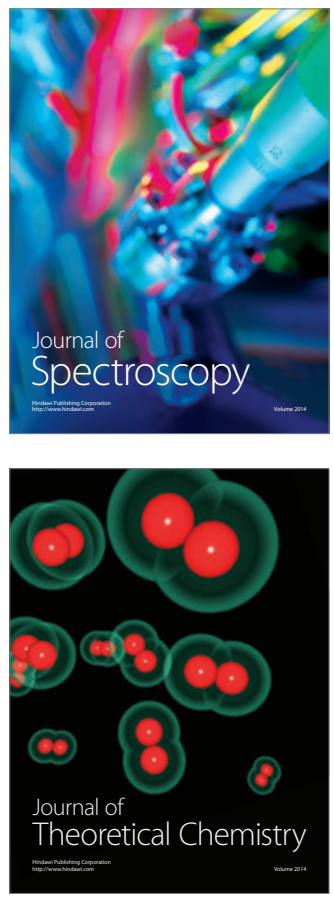
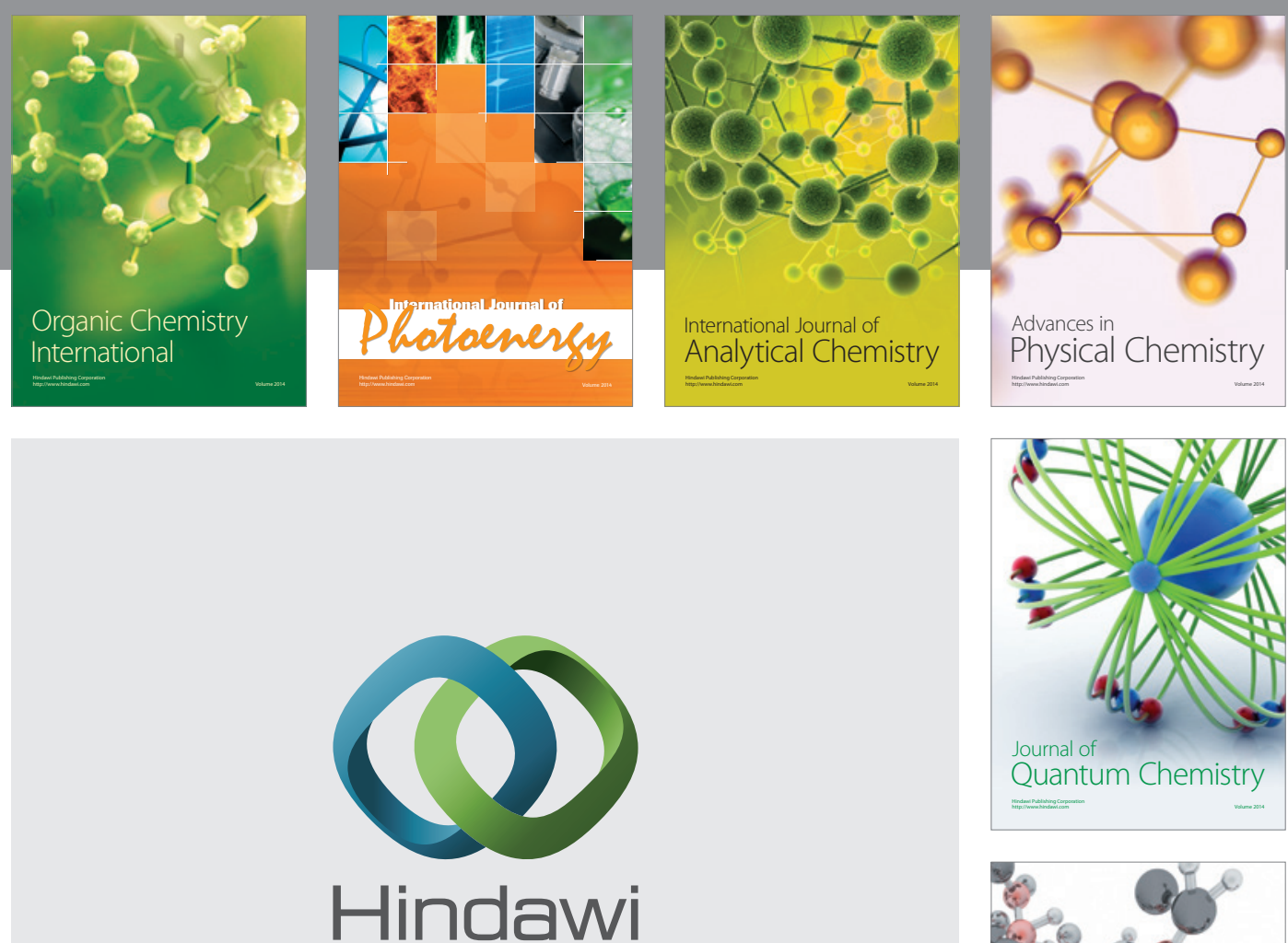

Submit your manuscripts at

http://www.hindawi.com

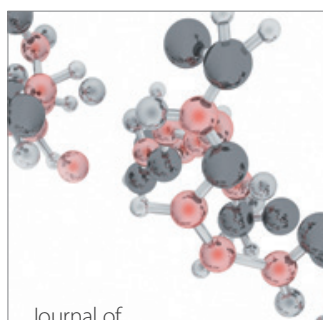

Analytical Methods

in Chemistry

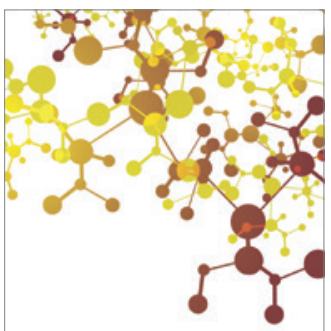

Journal of

Applied Chemistry

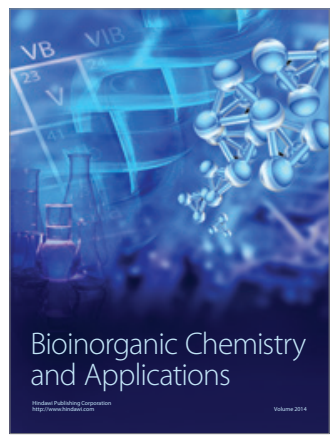

Inorganic Chemistry
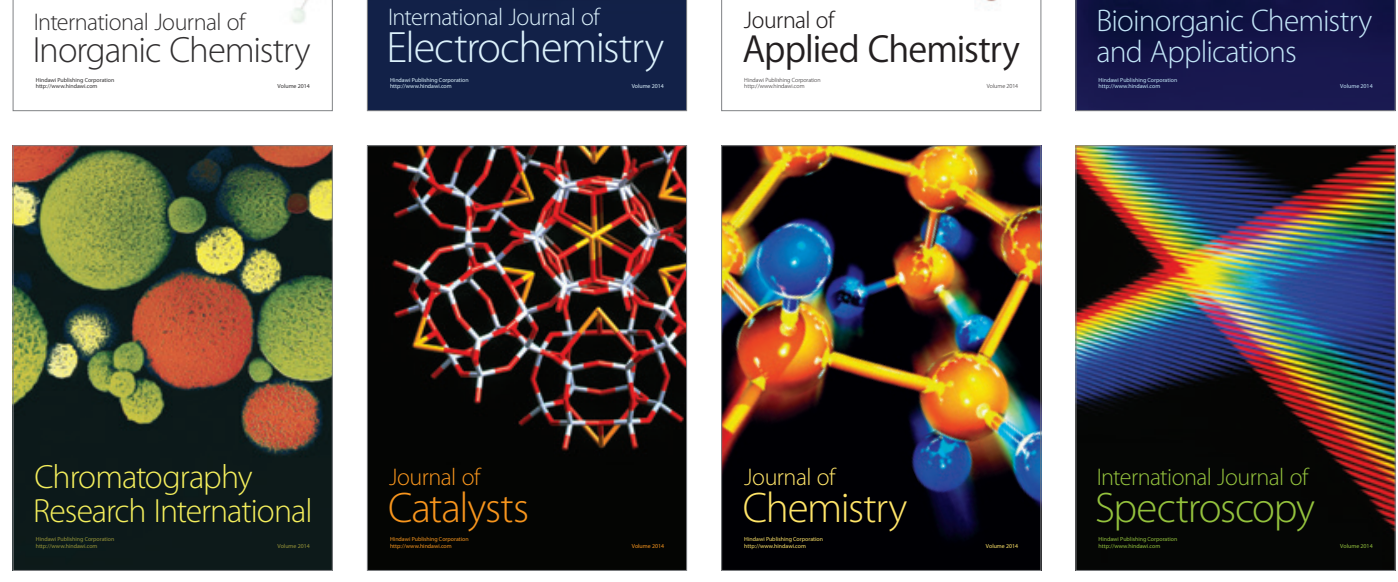